\title{
PENERAPAN KONSEP TRILOGY + 1 LEARNER DALAM MENCIPTAKAN PENDIDIKAN HUMANIS MELALUI PENINGKATAN PERAN DAN FUNGSI STAKEHOLDERS PENDIDIKAN DI SD
}

\author{
Mohammad Zaini \\ Yusvidha Ernata \\ IKIP Budi Utomo Malang \\ Jl. Arjuno No. 14 B Kota Malang \\ Email: success.zen@budiutomomalang.ac.id; yusvidha_ernata@yahoo.co.id
}

\begin{abstract}
This research aims to apply the concept of trilogy +1 learner at the humanist learning process in elementary school of Malang. The study used a phenomenological qualitative approach. The instruments used in-depth interviews, documentation, and observations with a grand theory analysis model based on humanist educational theory. The results of the study show that (1) the humanist education process through the role and function of stakeholders can be carried out through the concept of trilogy +1 learner which involves the guardians of students in all school activities, especially in the periodical learning process with a system of 1 week face to face, 1 lessons alternately. (2) The appreciation, sympathy, and empathy of the stakeholders of education, as well as the appreciation of children for the value of humanity, are increasingly better.
\end{abstract}

Keywords: trilogy +1 learner, humanist education, stakeholders, elementary school.

\begin{abstract}
Abstrak: Penelitian bertujuan menerapkan konsep trilogy +1 learner dalam proses pembelajaran humanis di SD kota Malang. Penelitian menggunakan pendekatan kualitatif fenomenologis. Instrumen yang digunakan meliputi indepth interview, dokumentasi, dan observasi. Model analisis yang digunakan grand theory berdasarkan teori pendidikan humanis. Hasil (1) proses pendidikan humanis melalui peran dan fungsi stakeholder dapat dilakukan melalui konsep trilogy +1 learner yakni melibatkan wali peserta didik dalam semua kegiatan sekolah, khususnya dalam proses pembelajaran yang dilakukan secara periodik dengan sistem 1 pekan 1 kali tatap muka, 1 mata pelajaran bergantian. (2) Apresiasi, simpati dan empati stakeholders pendidikan, serta apresiasi anak terhadap nilai humanitas semakin meningkat lebih baik.
\end{abstract}

Kata Kunci: trilogy+1 learner, pendidikan humanis, stakeholders, SD.

Proses pendidikan yang humanis di negara Indonesia dirasakan sangat mahal, dan dianggap tidak terlalu berlebihan kondisi realitasnya. Menurut penulis menganggap proses pendidikan humanis sebagai persoalan yang hampir langka. Pernyataan ini tentu berdasar dari berbagai pemberitaan di berbagai media cetak atau online, yang tidak asing menghiasi dalam setiap pemberitaan di kolom-kolom pendidikan (Surya, Sabtu, 6 September 2014; Malang Post, 23 September 2015; Radar Malang, 20 Januari 2016;
Surya, 17 November 2016; Malang Today, 17 November 2016; Surya, 29 November 2016). Dari sejumlah sampel kasus kekerasan pada media-media tersebut memperkuat pernyataan Ketua KPAI yang menyatakan bahwa Malang raya darurat kekerasan terhadap anak (Malang Today, 17 November 2016).

Pada tahun 2016 dilakukan penelitian yang menunjukkan bahwa terjadinya kekerasan terhadap anak dalam dunia pendidikan (Zaini, 2016). Pada satu sisi hal ini disebabkan oleh mindset guru yang 
masih menganggap bahwa dengan pola pendidikan yang tegas, maka cenderung peserta didik akan mudah terbentuk, baik sikap ataupun dalam hal karakternya. Namun demikian, istilah 'tegas' dalam hal operasional tidaklah mudah dibedakan dengan 'kekerasan'. Sebab bisa saja guru berargumentasi dengan logika ketegasan, namun sikap secara fisik menunjukkan perilaku kekerasan, yang dibuktikan dengan munculnya korban bagi peserta didik.

Kasus kekerasan pendidikan di wilayah Malang Raya, menurut data KPAI, Malang raya menempati posisi ke-6 dari $17 \mathrm{kota} /$ kabupaten yang ada di Jawa Timur. Sedangkan Jawa Timur sendiri menempati urutan ke-2 dari seluruh propinsi yang ada di Indonesia (Malang Today, 17 November 2016). Urutan angka tersebut adalah mendekati titik yang kritis. Oleh karena itu, dibutuhkan pembenahan secara menyeluruh, baik dari luar sistem terkait, lebih-lebih yang langsung berkaitan dengan 'bakal calon pelaku'. Dalam arti memberikan pembinaan kepada setiap elemen-elemen stakeholder pendidikan, yang tidak hanya berpusat pada komponen utama guru dan peserta didik, tetapi juga kepada wali dari peserta didik.

Upaya menerapkan gambaran konsep di atas, tentu dibutuhkan konsep teoritik sebagai dasar pedoman. Konsep teoritik dimaksud adalah konsep trilogy+1 learner. Konsep ini menggambarkan ide peningkatan peran dan fungsi stakeholder pendidikan, melalui keterlibatan wali peserta didik dalam sebuah iklim belajar sesuai peran dan fungsinya masing-masing untuk memberikan atensi dan pembelajaran bagi putra-putrinya. Konsep ini memaksimalkan layanan kemanusiaan yang memperlakukan guru, peserta didik, dan orangtua sebagai pelaku yang sama-sama aktif; koordinatif, komunikatif, dan apresiatif terhadap setiap pencapaian ilmu pengetahuan yang didapatkan, serta menjadikan IPTEK sebagai sasaran pengembangan pengembangan mentalitas peserta didik (Zaini, 2016:1). Adapun konsep trilogy +1 learner dimaksud, berkaitan dengan unsur subyek aktif dan obyek pasif. Subyek aktif mencakup pendidik, peserta didik, orang tua peserta didik, sedangkan obyek pasif yaitu ilmu pengetahuan.

Pada gambaran konsep trilogy +1 learner di atas, orangtua peserta didik juga diposisikan diri sebagai subjek aktif. Ketiga subjek tersebut samasama saling mengimbangi subjek aktif pendidik dan peserta didik, sehingga cara pandang dari ketiga subjek aktif tersebut sama-sama memposisikan ilmu pengetahuan sebagai objek. Ketiga-tiganya sama-sama belajar, berlatih, saling berkomunikasi, berkoordinasi dan berinteraksi mengenai ilmu pengetahuan yang menjadi objeknya. Guru di dalam kelas tidak menjadi pusat belajar (teacher centre), akan tetapi menjadi mitra belajar yang komunikatif dan interaktif bersama peserta didik. Peran dan fungsi guru di dalam dan di luar kelas menjadi elegan, sehingga atmosfer kelas sangat menyenangkan.

Secara sederhana dan umum peran dan fungsi guru bagi peserta didik dapat diidentifikasikan melalui 19 hal, diantaranya: guru sebagai pendidik, pengajar, pembimbing, pelatih, penasehat, pembaharu (innovator), model dan teladan, pribadi, peneliti, pendorong kreativitas, pembangkit pandangan, pekerja rutin, pemindah kemah, pembawa ceritera, aktor, emansipator, evaluator, pengawet, dan sebagai kulminator (Mulyasa, 2005:137). Melalui 19 peran tersebut, guru berada pada posisi yang sangat strategis. Sikap dan perilaku guru benar-benar berpengaruh terhadap perilaku peserta didik. Apabila didapatkan guru yang humoris dan menyenangkan bagi peserta didik, tentu secara kausalitas guru tersebut pada saat menjadi peserta didik mendapatkan pendidikan yang humoris dan menyenangkan, sehingga guru tersebut menjadi profile dalam setiap memori peserta didik. Begitu juga sebaliknya, maka guru akan menjadi mimpi buruk bagi peserta didiknya.

Realitas seperti di atas tentu menjadi persoalan yang krusial bagi berkembangnya kompetensi setiap guru/pendidik, mengingat persoalan tersebut seperti mata rantai yang tidak mudah diputus, selama paradigma yang digunakan menggunakan paradigma otoritatif yang menjadikan proses pembelajaran hanya berpusat pada guru (teacher centre), sehingga guru menjadi satu-satunya otoritas keilmuan. Paradigma tersebut diduga tidak mampu membawa visi besar kemanusiaan yang diharapkan dapat tumbuh dan berkembang secara baik di dalam setiap pribadi peserta didik. Sebaliknya, dibutuhkan peran serta stakeholders yang lain secara partisipatif, sehingga visi besar humanitas dapat dikawal dan dijalankan bersama oleh para stakeholders pendidikan. Adapun komponen stakeholders yang memiliki keterlibatan langsung dengan peserta didik, dan relevan dengan konsep trilogy +1 learner yakni (1) guru/pendidik sebagai person profesional yang 
memiliki otoritas mendidik, dan berfungsi sebagai orangtua kedua non genetik, dan (2) orangtua peserta didik sebagai penanggungjawab genetik yang memiliki hubungan langsung dan erat dengan peserta didik. Kedua komponen spesifik tersebut memiliki peran secara langsung dengan peserta didik sesuai dengan posisi peserta didik berada.

Oleh karena itu melalui penelitian ini ditujukan untuk mendesain sebuah program penerapan konsep trilogy +1 learner untuk menciptakan proses pendidikan humanis melalui peningkatan peran dan fungsi stakeholders pendidikan di kota Malang

Secara umum icon istilah dan ruang lingkup yang digunakan dalam dunia pendidikan selama ini adalah konsep 'tri pusat pendidikan', dengan cakupan; sekolah, keluarga dan masyarakat. Tentu teori tersebut bersifat universal, sangat luas, bahkan tidak mampu menyentuh aspek yang riil dan kongkrit. Oleh karena itu, istilah yang lebih spesifik menyentuh ruang dan area pembelajaran, lebih tepatnya menggunakan re-teori / re-terminologi; yakni "trilogy+1 learner."

Trilogy+1 learner merupakan trilogi ranah pendidikan yang selama ini kurang spesifik menjadi perhatian serius para pelaku pendidikan. Selanjutnya, akan ramai menuai perhatian apabila telah muncul kasus, dan seluruh stakeholder pendidikan memiliki kepedulian yang tinggi terhadap pendidikan. Pada realitas tersebut hanyalah musiman dan sebelumnya jauh dari ranah konsistensi perhatian dan kepedulian publik. Melihat dari realitas musiman perhatian dan inkonsistensi publik dalam mengawal tri pusat pembelajar di maksud, tentu hal ini akan menjadi masalah yang rumit dan komplek dalam dunia pendidikan. Pada akhirnya berbagai masalah pendidikan akan menjamur dan menjadi tidak mudah ditangani secara cepat.

Persoalan dehumanisasi dalam proses-proses pembelajaran seringkali menjadi masalah yang bersifat reguler dalam dunia pendidikan. Hal ini terjadi sepanjang tahun di berbagai tempat satuansatuan pendidikan. Tentu masalah utamanya adalah tidak sinerginya di antara ke tiga komponen tersebut (tri pusat pembelajar), yakni guru, peserta didik dan Orangtua. Dalam dunia pendidikan, ketiga komponen tersebut memegang peranan yang penting (very significant). Ketiganya merupakan kunci penentu di dalam menjalankan visi besar pendidikan, sebagaimana yang termaktub di dalam tujuan pendidikan nasional (UU. Sisdiknas No. 20 Tahun 2003, Pasal 3).

Pada tujuan pendidikan tersebut tergambar nilai-nilai luhur dan sekaligus pengharapan besar yang tersemat di dalam setiap pelaku pendidikan. Pelaku pendidikan sebagaimana tripusat pembelajar, sama-sama memiliki peranan yang saling bersambut dan saling mendukung. Ketiganya samasama bersinergi mewujudkan tujuan yang diusung, sehingga pada saatnya- impian besar tujuan pendidikan nasional tidak hanya menjadi sesuatu yang utopis, sebaliknya menjadi hal yang realistis. Freire (1995) mengatakan bahwa dalam sebuah proses pendidikan melibatkan tiga hal, yakni: pendidik, peserta didik dan ilmu pengetahun. Dalam arti pendidik, bersinergi dengan peserta didik, sama-sama sebagai subjek aktif, dan menjadikan ilmu pengetahuan sebagai objek pasif untuk selalu dapat dikembangkan sesuai perkembangan zaman.

Di dalam trilogy+1 learner, yang menjadi subjek aktif adalah pendidik, peserta didik, sebagai mitra yang sama-sama berposisi sebagai pembelajar dan orangtua peserta didik sebagai mitra komunikasi yang mendukung terhadap proses terjadi pembelajaran di sekolah. Sedangkan yang menjadi objek pasifnya adalah ilmu pengetahuan, sebagaimana pada gambar 1.

Oleh karena itu, memperbaharui konsep Freire dalam konteks pendidikan era kontemporer dengan berbagai tantangannya saat ini tentu membutuhkan/ melibatkan stakeholder inti lainnya, yang dalam hal ini adalah orangtua (wali) peserta didik. Sebagaimana kerangka konsep "relasi simbiosis the trilogy +1 learner" di atas, menggambarkan bahwa dalam proses penyelenggaraan pembelajar, guru $(\mathrm{G})$ tidaklah berposisi pemeran tunggal, akan tetapi guru berfungsi sebagai mitra koordinatif peserta didik. Selanjutnya, peserta didik (PD) dapat mengembangkan berbagai potensi dirinya dengan ide-ide kreatifnya, sehingga guru dapat menyupportnya, mengapresiasinya, serta memberikan penguatan-penguatan terhadap setiap capaian-capaian ilmu pengetahuahun (IP) yang didapatkan oleh peserta didik.

Sedangkan wali peserta didik (W.PD), berposisi sebagai mitra koordinatif-komunikatif dengan guru (G), sekaligus sebagai mitra apresiatif dengan peserta didik (PD). Tugas wali peserta didik adalah berupaya untuk mensinergikan pembiasaan baik yang didesain dan diterapkan di sekolah, berkoor- 
160 Sekolah Dasar: Kajian Teori dan Praktik Pendidikan, Tahun 27 Nomor 2, November 2018, hlm 155-166

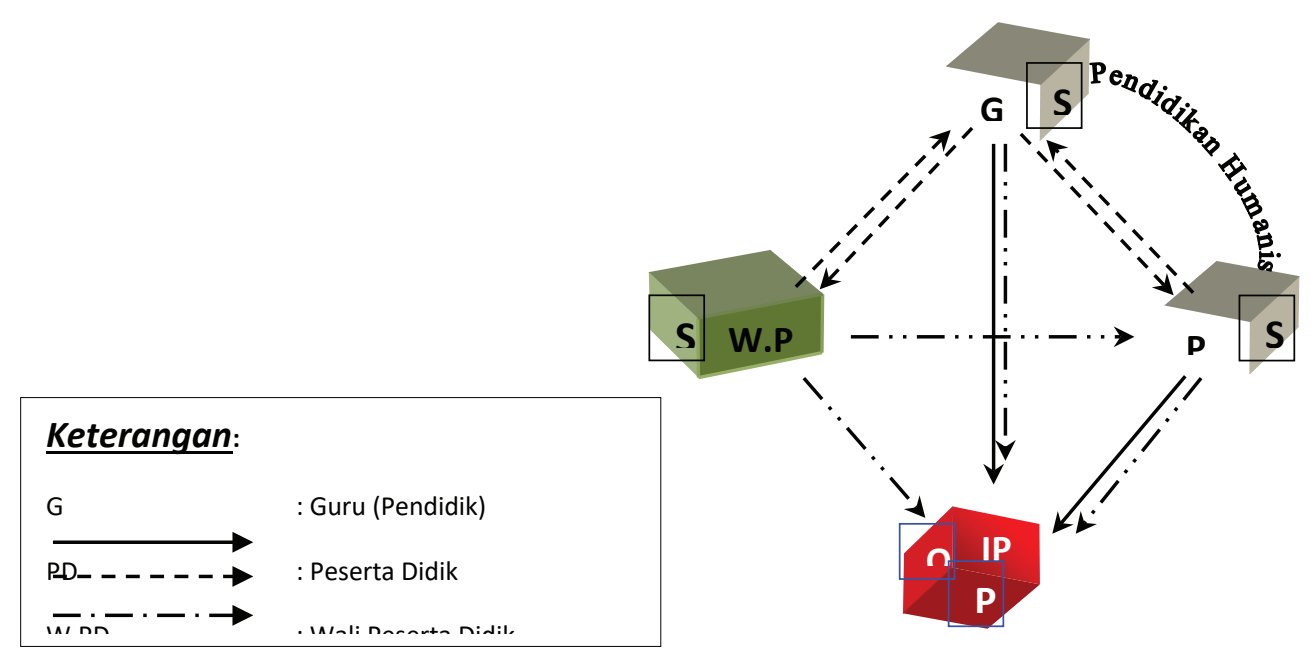


secara ramah, mengasihi dan menyayangi dengan baik.

\section{METODE}

Pendekatan kualitatif dengan desain fenomenologis, digunakan untuk mencapai tujuan tersebut dari penelitian ini. Teknik pengumpulan data menggunakan interview, dokumentasi, dan observasi. Sumber data utama dalam penelitian ini adalah kata-kata lisan melalui interview, tulisan melalui data dokumentasi, tindakan melalui data hasil observasi. Sedangkan data sekunder dalam penelitian ini, diantaranya; UU. Sisdiknas No. 20 Th. 2003, UUGD. No.14 Th. 2005, Kurikulum 2013, PP. 19 Th. 2005 SNP, PP. No. 74 Th. 2008 (Guru), Permendiknas, No. 16 Th 2007 tentang Standar Guru.

Data riil yang dibutuhkan dalam penelitian ini, diantaranya: kebijakan sekolah tentang keterlibatan wali peserta didik, cara pandang guru dalam proses pendidikan, latar belakang wali peserta didik (pendidikan \& profesi) dan capaian hasil belajar melalui Ujian Nasional, serta data kebijakan instruktif kedinasan (Kepsek/Kadispendik) yang dapat berpengaruh dalam proses pembejalaran dan dokumen terkait lainnya.

Sedangkan teknik analisis data yang digunakan adalah teknik analisis interaktif Miles \& Huberman (1987)yang dilakukan melalui empat tahap, yaitu: pengumpulan data, reduksi data, display data, serta penarikan kesimpulan dan verifikasi. Penelitian ini dilaksanakan di SDN Purwantoro7 dan SDN Buring kota Malang.

\section{HASIL}

\section{Kerangka Program Penerapan Konsep Trilogy+1 Learner}

Kerangka program dalam konteks penerapan konsep melalui penelitian ini dimulai dari konsep dan rencana strategis kurikulum yang ada di sekolah. Dari kedua SDN yang ada (SDN Purwantoro 7 dan SDN Buring) terdapat perbedaan yang tidak mudah disamakan.

SDN Purwantoro 7 cenderung lebih militan dalam hal maksimalisasi proses pembelajaran, meskipun belum maksimal melibatkan wali peserta didik. Karena berharap terhadap keterlibatan wali peserta didik, tentu merupakan hal yang tidak mudah direalisasikan, mengingat wali peserta didik memiliki latar belakang pendidikan yang rendah
(SLTA 46\%), dan disertai dengan profesi sebagai buruh lepas (swasta 42\%). Oleh karena itu menjadi tidak mudah untuk terlibat secara intensif di sekolah, mengingat waktu-waktu yang ada hanya secara fokus dimanfaatkan untuk memenuhi kebutuhan keseharian. Namun demikian tidak berarti bahwa wali peserta didik SDN Purwantoro7 tidak pernah terlibat, tetap terlibat meskipun hanya dalam hal pengambilan raport putra-putrinya, dan selebihnya kembali pada kesibukannya semula.

Sedangkan wali peserta didik pada SDN Buring sangatlah bertolak belakang dengan wali peserta didik di SDN Purwantoro7. Tampak dalam pengamatan di lapangan, bahwa keterlibatan para wali peserta didik sangat aktif, baik dalam hal pembelajaran di dalam kelas, dan juga pada kegiatan pembelajaran ekstra di luar kelas. Keterlibatan para 'wali' tidak hanya sebagai pengunjung pasif, akan tetapi lebih dari hal tersebut, yakni berperan serta aktif dalam peran-peran strategis. Sebagai contoh keaktifan para wali, diantaranya sebagai guru, sebagai panitia, sebagai penanggungjawab kegiatan drum band dan kegiatan seni hadrah. Meskipun secara tekstual belum tertuang sebagai program, namun demikian bentuk keterlibatan para wali selain merupakan bentuk dorongan kesadaran dari bawah, juga merupakan pro aktif kebijakan yang terdorong dari Kepala Sekolah. Kondisi tersebut seperti gayung bersambut, antara wali dan pihak sekolah saling bahu-membahu untuk mewujudkan kualitas pendidikan yang lebih bagus, terutama dampak positifnya terhadap peserta didik di sekolah.

Secara konseptual pada kedua lembaga pendidikan di atas sama-sama tidak menyertakan konsep program secara terstruktur. Dalam arti, bahwa kurikulum yang menjadi sumber acuan tidak ditemukan istilah 'keterlibatan' wali peserta didik, baik dalam hal pembelajaran di sekolah ataupun di luar sekolah. Tentu jika hal ini yang terjadi maka konsep pengembangan sekolah ke depan tidak akan stabil. Tradisi pelibatan wali peserta didik di sekolah tidak akan berkesinambungan, lebih-lebih apabila sekolah mengalami pergantian kepemimpinan. Oleh karena itu, desain program secara kontekstual merupakan hal yang 'hampir mutlak' untuk ada dan terencanakan ke dalam struktur program yang menjadi bagian dalam satu-kesatuan di dalam kurikulum. Konsep seperti ini sesungguhnya telah memiliki sandaran yuridis di dalam UU No. 20 Tahun 2003, tentang Sistem Pendidikan Nasional, 
bab 1 ketentuan umum pada ayat 11: "pendidikan formal adalah jalur pendidikan yang terstruktur dan berjenjang yang terdiri atas pendidikan dasar, pendidikan menengah, dan pendidikan tinggi". Ayat 13: "pendidikan informal adalah jalur pendidikan keluarga dan lingkungan," dan ayat 16: "pendidikan berbasis masyarakat adalah penyelenggaraan pendidikan berdasarkan kekhasan agama, sosial, budaya, aspirasi, dan potensi masyarakat sebagai perwujudan pendidikan dari, oleh, dan untuk masyarakat."

Dilihat dari ayat-ayat di atas, masing-masing di dalamnya belum menggambarkan tentang unity dalam satu pemahaman humanistik. Selanjutnya menjadi satu pemahaman humanistik ketika ketigatiganya menjadi satu-kesatuan landasan dalam proses pendidikan. Dalam arti, peran wali peserta didik yang awalnya memiliki peran yang tidak terlalu penting dan memiliki peran diluar signifikansi hasil pendidikan, kemudian diposisikan sebagai pemeran yang sama dengan guru dan peserta didik, walaupun stressingnya tetap tertuju pada peserta didik. Model pemeranan seperti ini kemudian disebut dengan trilogy+1 learner. Sebagai konsekuensinya, maka wali peserta didik disarankan untuk berkehendak aktif di dalam siklus konsep teori trilogy +1 leaner ini. Karena jika tidak aktif, maka proses pendidikan akan sama seperti sebelumnya, bahwa proses pendidikan berjalan secara normal. Dalam arti, proses pendidikan berjalan seperti biasa, dan istilah 'biasa' tersebut bermakna 'standar', tidak menunjukkan progres kualitas pendidikan yang lebih baik untuk masa-masa yang akan datang.

Sampai saat ini iklim dunia pendidikan di Indonesia secara nasional masih pada tahap proses pengembangan kualitas. Proses ini terjadi secara terus-menerus di berbagai daerah, sampai pula pada masing-masing satuan pendidikan. Pada level masing-masing satuan pendidikan yang menjadi penyebab lemahnya kualitas pendidikan, yakni humanitas dan peran keterlibatan wali peserta didik. Permasalah humanitas dalam konteks ini adalah bersifat soft negative, dalam arti, bahwa lemahnya keterlibatan wali peserta didik dalam dunia pendidikan menyebabkan kurangnya simpati dan empati terhadap peserta didik, dan hal ini akan berpengaruh terhadap kenyamanan anak dalam belajar.

Oleh karena itu dengan model pemeranan, yakni dengan peningkatan peran dan fungsi stakeholders dalam teori trilogy+1 learner diharapkan mampu meningkatkan kualitas pendidikan bagi anak. Adapun desain kerangka program penerapan konsep trilogy+1 learner pada gambar 2 .

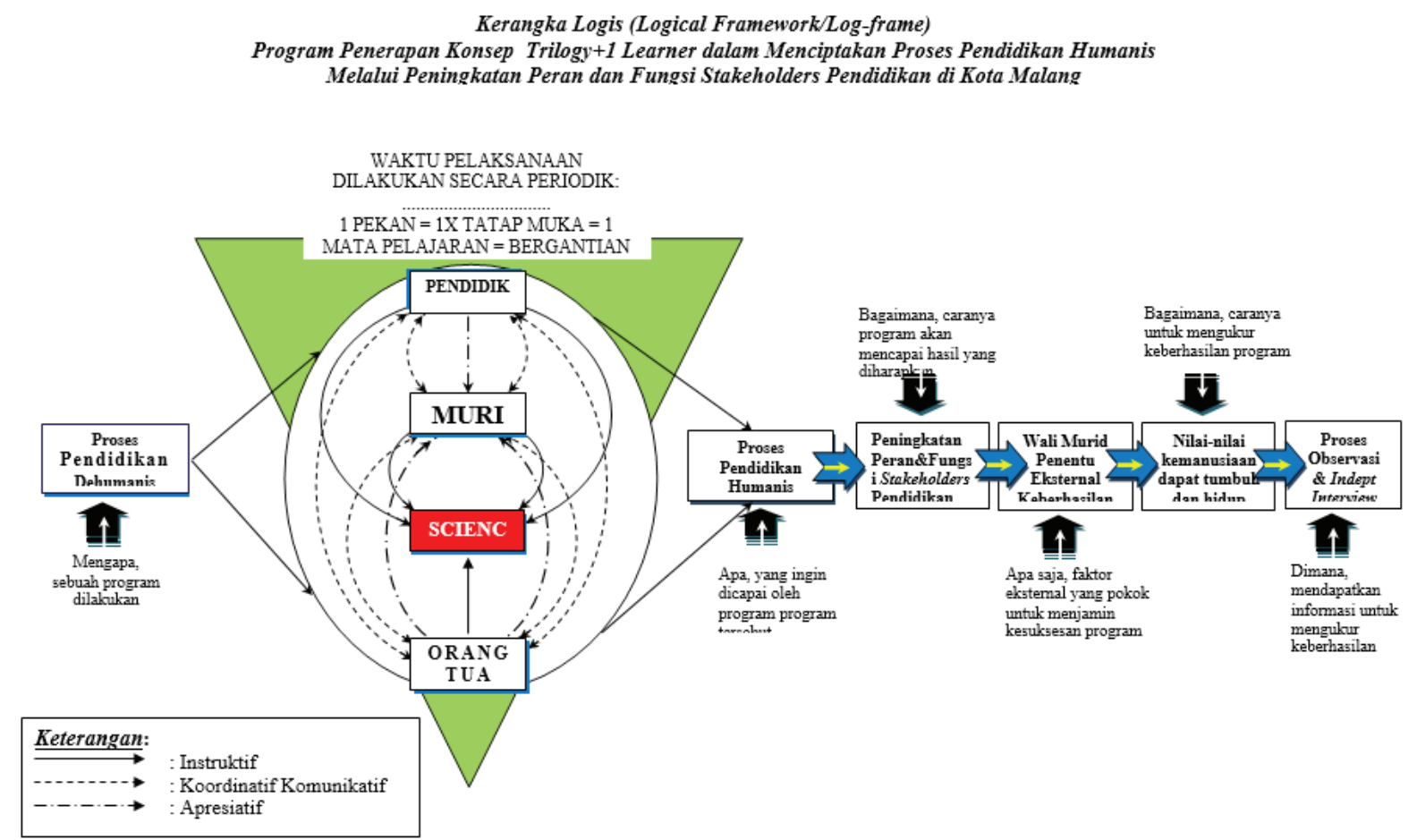

Gambar 2. Kerangka Logis Program Penerapan KonsepTrilogy+1learner 


\section{PEMBAHASAN}

Pada desain program konsep penerapan trilogi+1 learner, menggambarkan universalitas kualitas pendidikan yang akan dapat direalisasikan apabila semua unsur yang ada berperan aktif dan humanis. Kerangka program tersebut dimulai dari realitas dehumanis yang secara umum masih menjadi latar belakang pendidikan humanis. Dalam arti, bahwa proses pendidikan yang ada hari ini selalu bertolak dari masalah in-empaty dan ketidak simpatian pihak-pihak terkait terhadap peserta didik, mulai dari persoalan verbal dan non verbal dalam masyarakat pendidikan. Aktor-aktornya adalah pendidik dan wali peserta didik. Kedua aktor ini memiliki peranan yang sangat strategis dalam dunia pendidikan, terutama dalam hal berkaraktertidaknya peserta didik yang dididik. Oleh karena itu, jika kedua aktor ini dalam posisi yang sama, sama-sama bersimpati dan berempati pada peserta didik, maka bukan tidak mungkin kualitas pendidikan anak akan melejit dan membanggakan. Adapun makna yang tertanam dalam diri peserta didik adalah kebersamaan, keharmonisan, dialogis, empati, simpati, menghormati, menghargai, dan lain-lain. Inilah substansi dari karakter yang akan dibangun dalam dunia pendidikan. Selanjutnya lebih dari hal tesebut, yakni kualitas sain yang juga akan memudahkan mengayakan referensi dari peserta didik.

Freire (1995) dalam hal ini memberikan gambaran dalam siklus keterlibatan dunia pendidikan, yakni subjek pertama adalah guru, subjek kedua adalah murid dan objeknya adalah ilmu pengetahuan. Kedua subjek tersebut terjalin secara egaliter dalam proses belajar. Guru menjadi fasilititor terbaik dalam proses belajar, sehingga peserta didik tersupport dan mampu menguasai objek materi secara baik. Namun demikian, dalam konteks pendidikan di Indonesia teori Freire di atas secara umum tidaklah cukup. Dalam konsep pendidikan di Indonesia, Ki Hajar Dewantara mengenalkan tripusat pendidikan, yakni: lingkungan keluarga, lingkungan sekolah, dan lingkungan masyarakat.

Terdapat sesuatu yang sangat bermakna di dalam penjelasan Tripusat Pendidikan yaitu (1) keinsyafan Ki Hadjar Dewantara bahwa tujuan pendidikan tidak mudah dicapai melalui satu arah saja, (2) ketiga-pusat pendidikan hendaknya terjalin dengan sangat akrab dan penuh harmoni, (3) bahwa lingkungan keluarga adalah pusat belajar utama dan memfasilitasi pendidikan budi pekerti, agama, dan laku sosial (4)bahwa alam kemasyarakatan sebagai area terbuka media berlatih menumbuhkan karakter dan personalitinya, (5) pemikiran $\mathrm{Ki}$ Hadjar Dewantara adalah upaya menumbuhkan dan menghidupkan, mengembangkan dan menguatkan rasa sosialitas yang tinggi di dalam diri anak.

Adapun titik tolak dari konsep yang dibawa Paulo Freire dan Ki Hajar Dewantara, selanjutnya melahirkan sintesis teori baru yang dikenal dengan trilogy+1 learner, dikenalkan oleh Zaini (2016). Teori ini selanjutnya include di dalam kerangka program (sebagaimana gambar 2) yang menjadi dasar utama di dalam menciptakan proses pendidikan humanis dan peningkatan peran dan fungsi stakeholders pendidikan. Peran secara umum wali peserta didik adalah menjadi mitra terbaik bagi sekolah melalui hubungan baik antara wali peserta didik dengan seluruh unsur sekolah di mana peserta didik (sebagai putra/putrinya) belajar. Tentu hubunngan baik ini dimulai dari hubungan baik orangtua dengan peserta didik sebagai putra/ putrinya di lingkup keluarga. Hasil penelitian Nakao et al. (2000) di Osaka, Jepang menemukan bahwa lingkungan keluarga memiliki pengaruh utama terhadap pembentukan kepribadian anak (pribadi berkualitas).

Selain dari itu, teori pembelajaran sosial menyatakan bahwa anak mempelajari suatu perilaku melalui pengamatan dan hubungan langsung dengan orang lain yang berada di sekitarnya (Miller, 2011). Hubungan langsung dengan orang lain dimaksud adalah hubungan interaktif, -yang ketika ditarik ke dalam konteks trilogy +1 learner, hubungan interaktif dapat berarti hubungan yang melibatkan dan menghadirkan ke empat unsur tersebut. Guru tidak lagi memposisikan diri sebagai orangtua, tetapi tetap sebagai guru, orangtua peserta didik tetap dalam posisinya sebagai orangtua secara biologis, peserta didik sebagai anak dan peserta didik di kelas, dan ilmu pengetahua betul-betul menjadi ladang yang siap diolah bersama dalam rangka menghasilkan produksi baru dalam ilmu pengetahuan.

Dengan demikian, keempat unsur tersebut betul-betul pada posisi yang sebenarnya, tidak sedang memposisikan diri dengan posisi berbeda, sehingga peserta didik betul-betul menghadapi dunia nyata (the real world) di dunianya. Dalam konteks ini adalah sama dengan memasukkan 
formulasi keluarga ke dalam lingkup sekolah dalam hal pembelajaran, sehingga keempat-empatnya hadir, sebagai pendidik, peserta didik, wali peserta didik dan ilmu pengetahuan dalam satu momentum keilmiahan.

Adapun peran dan fungsi stakeholoders pendidikan (wali peserta didik) sesuai dengan keputusan Menteri Pendidikan Nasional Nomor 044/U/2002, disandarkan pada peran dan fungsi komite sekolah adalah sebagai berikut: (a) pemberi pertimbangan (advisory agency) dalam penentuan dan pelaksanaan kebijakan pendidikan di satuan pendidikan, (b) pendukung (supporting agency), baik yang berwujud finansial, pemikiran, maupun tenaga dalam penyelenggaraan pendidikan di satuan pendidikan, (c) pengontrol (controlling agency) dalam rangka transparansi dan akuntabilitas penyelenggaraan dan pengeluaran pendidikan di satuan pendidikan, (d) mediator antara pemerintah (eksekutif) dengan masyarakat di satuan pendidikan (Kepmendiknas No. 044/U/2002, Tgl. 2 April 2002 tentang Dewan Pendidikan dan Komite Sekolah).

Keempat peran dan fungsi stakeholders pendidikan di atas menggambarkan bahwa stakehloders pendidikan betul-betul pada posisi terlibat aktif, juga memilik tanggung-jawab atas sekolah yang menjadi tempat belajar putra/putrinya. Hal ini mengakibatkan secara ideal tidak ada satupun fungsi dan peran menyebabkan berjaraknya hubungan antara wali peserta didik dengan sekolah. Sekolah diposisikan sebagai bagian yang tidak terpisah dengan lingkup keluarganya, dalam arti memiliki visi yang sama dalam hal humanisasi peserta didik secara umum.

Pertama, peran pertimbangan yang diberikan oleh wali peserta didik. Dalam hal ini peran diberikan tidak hanya karena diminta, akan tetapi peran ini melekat dalam diri orangtua sebagai wali peserta didik, sehingga keberadaan hadir secara integratif, menjadi bagian yang tidak terpisahkan dengan visi yang diusung sekolah. Keberadaanya berkontribusi di dalam menentukan langkah kebijakan yang akan diambil oleh sekolah. Karena disadari bahwa kebijakan tersebut akan memberi dampak bagi masyakat sekolah seluruhnya yang secara khusus berdampak kepada peserta didik.

Kedua, peran pendukung; finansial, pikiran, maupun tenaga penyelenggaraan pendidikan. Peran ini merupakan bagian yang akan menentukan bagi berlangsung baik/tidaknya proses dan hasil pembelajaran anak. Oleh karena itu dalam hal ini wali peserta didik memiliki peranan yang strategis, mengingat subjek pembelajarnya adalah putra/ putrinya sendiri.

Ketiga, peran pengontrol. Peran ini memberikan garansi terhadap transparansi dan akuntabilitas penyelenggaraan pendidikan. Wali peserta didik dikehendaki memiliki fungsi yang baik untuk memberikan pengawasan, sehingga proses transparansi dan akuntabilitas dapat berjalan dengan baik.

Keempat, peran mediasi. Wali peserta didik selain sebagai bagian dari masyarakat, sebagai orangtua, bahkan juga sebagai anggota komite. Dalam hal ini wali peserta didik juga dapat berposisi sebagai 'jembatan penghubung antara sekolah dengan pemerintah, tidak terkecuali terkait dengan persoalan pembelajaran yang ada di sekolah. Oleh karena itu, ketika peran-peran di atas dapat diwujudkan ke dalam setiap sikap dan respon aktif wali peserta didik, tentu akan memberikan pengaruh yang sangat positif bagi sekolah pada umumnya, dan peserta didik pada khususnya.

Dalam suatu cuplikan, pada Stories about Harvard Family Research Project, disebutkan: The teacher recites what she needs to convey, the parents struggle to remember all the questions they'd wanted to ask, and everyone tries to make it meaningful - in the 15 minutes they're allotted for the meeting. Pada kutipan tersebut menggambarkan bahwa ada peran keterlibatan yang intensif antara ke empat unsur, guru, murid, dan orangtua terhadap suatu pengetahuan, dan orangtua mencoba untuk memahami dan membuat keberadaan/ keterlibatannya begitu bermakna. Model full motivation ini diyakini akan mampu menjadikan anak memiliki perangai humanis, berkarakter, baik hubungannya dengan sikap diri dan terhadap lingkungan sekitarnya. Hubungan keempat unsur tersebut begitu sangat dekat, natural dan hangat, sehingga tidak ada batas ruang dan waktu diantara ke empat unsur tersebut.

Begitu pula dikuatkan oleh suatu penelitian di Vanderbilt University dikatakan bahwa partisipasi orang tua bukan merupakan proses yang statis tapi berlangsung sepanjang waktu dan sangat dinamis. Selain orang tua, sekolah, anak-anak dan lingkungan sosial juga secara bersamaan memegang peranan penting dalam proses ini. Oleh karena itu, ke-ikutsertaan orangtua proses pendidikan anak/ peserta didik merupakan suatu yang memberikan 
angin segar bagi tumbuh berkembangnya nilai humanitas dalam diri anak. Nilai ini tentu menjadi tanggungjawab bersama, tidak dikhususkan kepada pendidik, akan tetapi dikawal bersama pula oleh wali peserta didik. Sebagaimana pandangan Weiss ....penelitian selama lima tahun terakhir menunjukkan bahwa konferensi orangtua-guru tradisional "adalah model yang diperlukan tetapi tidak cukup untuk berbagi kekuatan dan tantangan siswa. Keterlibatan keluarga "bukan satu peristiwa," ini adalah tanggung jawab bersama di mana komunikasi dua arah yang teratur menjamin bahwa siswa berada di jalur untuk memenuhi persyaratan tingkat kelas. Hal ini didasarkan pada kepercayaan dan saling menghormati dan mengakui bahwa semua keluarga memiliki tujuan, nilai, dan keterampilan untuk membantu anak-anak mereka berhasil dari pra-sekolah sampai sekolah menengah, dan seterusnya.

Dari pernyataan di atas menggambarkan bahwa orangtua sebagai stakeholder pendidikan bagi sekolah tidak hanya sebatas memiliki hubungan struktural oleh karena anaknya sebagai peserta didik di lembaga pendidikan. Akan tetapi lebih dari hal tersebut, orangtua juga memiliki hubungan 'emosional', komunikasi dua arah dengan pendidik dalam banyak peristiwa yang rutin, serta menghadirkan kebermaknaan dalam setiap momentum. Dengan begitu, para orangtua, dan guru sebagai bagian dari stakeholder mampu memberikan garansi yang lebih baik bagi anak/peserta didik di masa yang akan datang.

\section{SIMPULAN DAN SARAN}

\section{Simpulan}

Berdasarkan hasil pengambilan data dan analisis yang peneliti lakukan, maka dapat disimpulkan, bahwa: proses pendidikan humanis melalui peningkatan peran dan fungsi stakeholder pendidikan dapat dilakukan melalui program penerapan konsep trilogy +1 learner yakni melibatkan wali peserta didik, bersama pendidik, dan peserta didik dalam 'semua kegiatan' sekolah, khususnya dalam proses pembelajaran yang dilakukan secara periodik. Kegiatan tersebut dilakukan dengan sistem 1 pekan $=1 \mathrm{x}$ tatap muka $=1$ mata pelajaran $=$ bergantian. Melalui program ini, maka apresiasi, simpati dan empati stakeholders pendidikan, serta apresiasi anak terhadap nilai humanitas di lingkungan akan semakin meningkat lebih baik.

\section{Saran}

Konsep trilogy+1 learner merupakan konsep sintesis dari tripusat pendidikan (Ki Hajar Dewantara) dan relasi subjek-objek: guru, murid dan ilmu pengetahuan (Paulo Freire). Melalui konsep trilogy+1 learner ini, diharapkan lembaga pendidikan terkait (khususnya SDN Purwantoro 7, SDN Buring dan Diknas di kota Malang dapat meningkatkan kualitas pendidikan humanis secara maksimal.

Diantara saran terkait pendidikan humanis yaitu: (a) adanya kesepakatan tertulis, tersistem di dalam kurikulum- antara pendidik (sekolah) dan wali peserta didik tentang keterlibatan secara periodik di sekolah (proses pembelajaran), (b) dibangunnya komunikasi intensif antara pendidik dan wali peserta didik secara simbiosis, sehingga proses pendidikan humanis lebih mudah diwujudkan, (c) dibangunnya kepercayaan (trust) yang tinggi terhadap wali peserta didik untuk juga terlibat dalam kegiatan ekstra kurikuler, baik sebagai 'pembina' atau sebagai pendukung pada aspek-aspek tertentu sesuai dengan kapasitasnya, dan (d) Diknas kota Malang, diharapkan hasil penelitian ini (program konsep trilogy+1learner) menjadi suatu pertimbangan kebijakan untuk dapat diterapkan sebagai pilot project di kota Malang.

\section{DAFTAR RUJUKAN}

Biografipedia. 2015. Biografi Ki Hajar Dewantara Bapak Pendidikan Nasional. Diakses 24 Pebruari 2017 dari http://www.biografipedia. com/2015/08/biografi-ki-hajar-dewantara.html.

Insipirasi. 2018. Pentingnya Keterlibatan Orangtua dalam Pendidikan Anak. diakses 27 Juli 2018 dari https://axa.co.id/inspirasi/pentingnya-keterlibatan-orang-tua-dalam-pendidikan-anak-2/

Keputusan Menteri Pendidikan Nasional Nomor 044/U/2002 tanggal 2 April 2002 tentang Dewan Pendidikan dan Komite Sekolah

Malangtoday. 2016. Ketua KPAI : Malang Darurat Kekerasan Pada Anak. diakses 10 Mei 2018 dari http://malangtoday.net/malang-raya/ketuakpai-malang-darurat-kekerasan-pada-anak/

Miller PH. 2011. Theories of Developmental Psychology: Fifth Edition. New York: Worth Publishers.

Mulyasa, 2005. Menjadi Guru, Menciptakan Pelajaran Kreatif dan Menyenangkan, Bandung: Remaja Rosdakarya 
Nakao K, Takaishi J, Tatsuta K, Katayama H, Iwase M, Yorifuji K, Takeda M. 2000. The influences of family environment on personality traits. Psychiatry and Clinical Neurosciences. 54: 91-95

Serambinews. 2018. 5 Tragedi Memilukan saat Perayaan Kelulusan Siswa SMA, Dari Nyawa Melayang hingga Tawuran Berdarah. Diakses 9 Juli $2018 \mathrm{http}: / /$ aceh.tribunnews. com/2018/05/03/5-tragedi-memilukan-saatperayaan-kelulusan-siswa-sma-dari-nyawamelayang-hingga-tawuran-berdarah?page $=3$.

Surya. 2014. Kasus Kekerasan Siswa, Upaya Damai Dindik Malang Buntu. diakses 24 april 2018 dari http://surabaya.tribunnews.com/2014/09/06/ kasus-kekerasan-siswa-upaya-damai-dindikmalang-buntu.

Suryamalang. 2016. Miris, 84 Persen Siswa Pernah Alami Kekerasan di Sekolah. diakses 25 Mei 2018 dari http://suryamalang.tribunnews. com/2016/11/29/miris-84-persen-siswa-pernah-alami-kekerasan-di-sekolah.

Suryamalang. 2016. Ternyata, Masih Ada Kekerasan dalam Dunia Pendidikan di Kota Malang. diakses 25 mei 2018 dari http://suryamalang.tribunnews.com/2016/11/17/ternyata-masih-ada-kekerasan-dalam-dunia-pendidikan-di-kota-malang.
Tutorial penelitian. 2014. Triangulasi dan Validitas Penelitian Kualitatif diakses 6 Mei 2017 dari http://tu.laporanpenelitian.com/2014/11/22.html

Undang-Undang Nomor 20 Tahun 2003 Sistem Pendidikan Nasional. Jakarta: Kemenristekdikti

Usuable Knowlegde. 2015. Parent-Teacher Partnership Four trends reshaping the traditional parent-teacher conference. diakses 10 juli 2018 dari https://www.gse.harvard.edu/news/ uk/15/10/parent-teacher-partnership

Wulandari, Yeni. \& Kristiawan, Muhammad. 2017. Strategi Sekolah dalam Penguatan Pendidikan Karakter bagi Siswa dengan Memaksimalkan Peran Orang Tua. Jurnal Manajemen, Kepemimpinan, dan Supervisi Pendidikan. Diakses 6 Juli 2018 dari https://jurnal.univpgripalembang.ac.id/ index.php/JMKSP/article/\%20view/1477/1288

Zaini, Mohammad. 2016. Kajian Perilaku Humanitas Pendidik Terhadap Peserta Didik Dalam Proses Pendidikan di Kota Malang. JINoP (Jurnal Inovasi Pembelajaran). 2(2). 373-388 